\title{
AN APPRAISAL OF METHODS OF TISSUE CHLORIDE ANALYSIS: THE TOTAL CARCASS CHLORIDE, EXCHANGEABLE CHLORIDE, POTASSIUM AND WATER OF THE RAT ${ }^{1}$
}

\section{By DONALD B. CHEEK ANd CLARK D. WEST with THE TECHNICAL ASSISTANCE OF CATHERINE CARTER GOLDEN AND ELEANOR M. DOYLE}

\section{(From The Children's Hospital Research Foundation and the Department of Pediatrics, University of Cincinnati, Cincinnati, Ohio)}

(Submitted for publication May 26, 1955 ; accepted August 17, 1955)

Recent evidence $(1,2)$ promises to establish even more firmly the older concept that chloride in muscle is predominantly extracellular (3-5). On this premise investigators may find further credence in the use of chloride for the study of exchanges of fluid and electrolyte between the extra- and intracellular phases of this tissue. Obviously a method of high accuracy for the determination of tissue chloride is necessary if knowledge concerning body cell composition is to progress. Concern as to the accuracy of present methods arises when one considers the normal values for the chloride content of muscle, as obtained in various laboratories. Perusal of the literature reveals values for normal rat muscle ranging from 3.13 to $6.41 \mathrm{mEq}$. per 100 grams of fat free, dry solid $(6,7)$. Although the homogeneity of the tissue samples and/or the methods of determination may be questioned, the argument remains that as yet no means are at hand for ascertaining whether all the chloride in tissue has been measured (8).

Apart from the analyses of isolated tissues, investigations by many workers have sought to determine the extracellular volume and electrolytes in the whole animal by measuring the volume of distribution of various substances that either follow the distribution of chloride or do not penetrate cell water. If these data are to be compared with the volume of distribution of an isotope of chloride or bromide in the whole animal (9), it is important that we know how closely the volume of distribution of $\mathrm{Cl}^{36}, \mathrm{Cl}^{38}$, or $\mathrm{Br}$ predicts the true total body chloride.

1 This investigation was supported in part by research grants (H-1638) from the National Heart Institute and (A-306) from the National Institute of Arthritis and Metabolic Diseases of the National Institutes of Health, United States Public Health Service.
The present investigation attempts to throw some light on these questions by comparing in rats the total body chloride, as determined by the distribution of stable bromide, with the actual total chloride as determined by carcass analysis. Because the success of such a study depends in large part on the exact determination of carcass chloride, the accuracy of existing methods for tissue chloride also had to be assessed. The methods investigated were the commonly used open Carius method, employing silver nitratenitric acid digestion, and an alkaline ashing procedure with final determination of chloride titrimetrically, using the Conway microdiffusion technique. The accuracy of the methods have been assessed, first, by comparing the results with those for total body chloride determined by bromide distribution, and secondly, by relating carcass chloride to lean body mass. Total body water and total potassium also have been measured in rats of varying ages and weights and related to lean body mass.

\section{METHODS}

Thirty-five rats of varying weights and ages were placed on a low residue diet ${ }^{2}$ containing $26 \mathrm{mEq}$. of sodium and chloride and $167 \mathrm{mEq}$. of potassium per kilogram. Ten additional rats were placed on the same diet but 0.9 per cent sodium chloride solution was given for drinking in place of tap water. After one week the animals were injected intramuscularly with 2 per cent sodium bromide, $0.3 \mathrm{ml}$. per 100 grams body weight, from a preweighed syringe, and two to three hours later their

2 The constituents of the diet in grams per kilogram of the final mixture were as follows: vitamin free casein, 300 ; vitamin fortification mixture (Nutritional Biochemicals Corp., Cleveland, Ohio), 20 ; lard, 100 ; sucrose, 270; dextrose, $270 ; \mathrm{CaCO}_{3}, 13.5 ; \mathrm{Ca}\left(\mathrm{H}_{2} \mathrm{PO}_{4}\right)_{2}, 1.7 ; \mathrm{Ca}_{3}\left(\mathrm{PO}_{4}\right)_{2}$, $1.7 ; \mathrm{Fe}\left(\mathrm{C}_{6} \mathrm{H}_{8} \mathrm{O}_{8}\right) \cdot 3 \mathrm{H}_{2} \mathrm{O}, 1.2 ; \mathrm{MnSO}_{4} \cdot 4 \mathrm{H}_{2} \mathrm{O}, 0.2 ; \mathrm{ZnCl}_{2}$, $0.01 ; \mathrm{CuSO}_{4}, 0.01 ; \mathrm{MgSO}_{4}, 4.6 ; \mathrm{K}_{2} \mathrm{HPO}_{4}, 14.5 ; \mathrm{KI}, 0.07$; $\mathrm{NaCl}, 1.5$. 
fur was removed by electric clippers under Nembutal anesthesia. The animals were weighed, and blood was drawn from the aorta for serum bromide and chloride determinations. Each animal was then sacrificed, the carcass cut longitudinally, placed in a weighed beaker and dried to a constant weight at $105^{\circ} \mathrm{C}$. over a fourday period. The blood drawn for bromide and chloride determination was centrifuged, the volume of serum measured, and the red cells added to the carcass before drying. Total body water was calculated from the weight loss. When drying was complete, the carcass was crushed to a homogeneous aggregate in a mortar and a 40-gram specimen (representing all, or nearly all, of the carcass in most instances) was placed in four or five Soxhlet thimbles, weighed, and fat extracted for eight hours with petroleum ether in the Soxhlet apparatus. The thimbles were then removed, exposed to the air for two hours, placed in a drying oven at $105^{\circ} \mathrm{C}$. for one hour, reweighed, and the amount of fat extracted was calculated from the weight loss. The fat free, dry carcass was then reduced to a 60 mesh powder by grinding in a Wiley laboratory mill and homogenized by thorough mixing. The carcass was then considered to be suitable for analysis and placed in an air-tight container.

The methods for serum bromide determination and for calculating total chloride have been previously described $(10,11)$. For convenience with respect to ashing of the serum for the bromide determination, the following slight modification was introduced. The one-ml. aliquot of serum was placed in a platinum crucible, four drops of $2 \mathrm{~N} \mathrm{KOH}$ added, and the mixture digested on a water bath for two hours. When the digestion mixture was dry, the crucible was placed in a muffle furnace at $550^{\circ} \mathrm{C}$ for one hour. After cooling, the ash was dissolved in 1.2 or $1.5 \mathrm{ml}$. of $0.3 \mathrm{~N} \mathrm{H}_{2} \mathrm{SO}_{4}$ and a one-ml. aliquot placed in the outer chamber of the No. 2 porcelain Conway unit for bromide determination (12). Bromide assays were done in duplicate on each rat. To obtain a blank value for serum bromide, serum was taken from six additional rats which had been on the same diet and had not received bromide. This value, resulting from traces of bromide in the diet, averaged 20 $\mu \mathrm{gm}$. of bromide per $\mathrm{ml}$. In rats receiving bromide, the serum bromide concentrations were $160 \mu \mathrm{gm}$. per ml. or slightly greater. In the experiments in which saline replaced tap water for drinking, urine was collected after injection of bromide and correction was made for the small amount of bromide excreted prior to exsanguination. In the rats receiving tap water, the amount of bromide excreted during this period was not detectable.

Serum chloride was determined by the method of Van Slyke (13).

For the determination of carcass chloride, three procedures were used: 1) The open Carius method with digestion by heating on a hot plate; 2) the open Carius method with digestion in a boiling water bath; and 3 ) alkaline ashing of the carcass with chloride determination by the microdiffusion technique of Conway (12).

The procedure for the open Carius method was that of Van Slyke (13) with the modifications of Wilson and Ball (14) and of Hastings and Eichelberger (15). In both methods 1) and 2) above, the procedure was the same except for the temperature of digestion. Samples of powdered carcass weighing approximately $150 \mathrm{mg}$. were added to $1.0 \mathrm{ml}$. of $0.075 \mathrm{~N} \mathrm{AgNO}_{3}$ and the sides of the tube washed with $5 \mathrm{ml}$. of water. The mixture was then allowed to stand for 16 to 20 hours at $4^{\circ} \mathrm{C}$. Two ml. of concentrated nitric acid were then added and the mixture digested for two to four hours with frank boiling but without bumping on a hot plate at "medium" heat (method 1), or by immersion for 6 hours in a boiling water bath (method 2). During digestion the tubes were covered either with inverted glass thimbles or with funnels. The temperature of the mixture during digestion using the hot plate for heating was $104^{\circ}$ to $105^{\circ} \mathrm{C}$. and, using the water bath, $96^{\circ}$ to $97^{\circ} \mathrm{C}$. Several drops of hydrogen peroxide were added after digestion had proceeded for a time. At completion of digestion under these conditions, the mixtures were nearly colorless. After cooling the tubes, ferric alum was added and the mixture titrated with $0.02 \mathrm{~N} \mathrm{NH}_{4} \mathrm{CNS}$ in an ice bath.

For determination of chloride by the alkaline ashmicrodiffusion method, samples of powdered carcass weighing approximately 150 milligrams were placed in platinum crucibles, $0.5 \mathrm{ml}$. of $2 \mathrm{~N} \mathrm{KOH}$ were added, and the mixture digested on a steam bath for two hours. When the digestion mixture was dry, the crucible with cover was placed in a muffle furnace at $550^{\circ} \mathrm{C}$. for one hour. A white ash was obtained and after cooling, 0.3 ml. of $4 \mathrm{~N} \mathrm{H}_{2} \mathrm{SO}_{4}$ were added and the contents of the crucible washed over into a $10-\mathrm{ml}$. volumetric flask and made to volume with distilled water. Four aliquots, each of $1.0-\mathrm{ml}$. volume, were placed in the outer chambers of four No. 2 porcelain Conway units ${ }^{3}$ and chloride estimated by liberating free chlorine and displacing an equivalent amount of iodine from potassium iodide as described by Conway (12). Following the two-hour period of microdiffusion, the free iodine liberated was titrated with a microburette containing $0.01 \mathrm{~N} \mathrm{Na}_{2} \mathrm{~S}_{2} \mathrm{O}_{3}$, using starch as the indicator. With each set of determinations, standards, consisting of $1.0 \mathrm{ml}$. of a $4 \mathrm{mEq}$. per liter solution of $\mathrm{KCl}$, were run in quadruplicate. For reasons which were not apparent, the titration figure for the standards varied slightly from day to day. By using the titration factors for standards which had been run concurrently, reproducible values were obtained for the unknowns.

For potassium estimation 150 milligrams of carcass

3 The following procedure was used in the cleaning of the Conway dishes: The units were first soaked in very dilute oxalic acid solution to remove permanganate stains, washed in running tap water, heated to boiling in a strong solution of a chloride-free detergent, wiped thoroughly with muslin and placed in running tap water. They were then soaked in $0.02 \mathrm{~N}$ sulfuric acid, rinsed once in tap water and eight to ten times in distilled water and finally dried in an oven at $105^{\circ} \mathrm{C}$. Careful attention to cleaning was essential for reproducibility of the titrations. 
TABLE I

\begin{tabular}{|c|c|c|c|c|c|c|c|}
\hline $\begin{array}{l}\text { Rat } \\
\text { no. }\end{array}$ & $\begin{array}{c}\text { Weight } \\
\boldsymbol{g m} .\end{array}$ & $\begin{array}{c}\text { Fat free } \\
\text { dry } \\
\text { solid } \\
\text { gm. } \\
\end{array}$ & $\begin{array}{c}\text { Total } \\
\text { water } \\
m l .\end{array}$ & $\begin{array}{c}\text { Lean } \\
\text { body } \\
\text { mass } \\
\text { gm. }\end{array}$ & $\begin{array}{l}\text { Carcass } \\
\text { chloride* } \\
m E q .\end{array}$ & $\begin{array}{c}\text { Bromide } \\
\text { exch. } \\
\text { chloride } \\
m E q .\end{array}$ & $\begin{array}{c}\text { Carcass } \\
\text { potassium } \\
m E .\end{array}$ \\
\hline $\begin{array}{r}6 \\
8 \\
10 \\
12 \\
13 \\
14 \\
15 \\
16 \\
17 \\
18 \\
19 \\
20 \\
21 \\
22 \\
23 \\
24 \\
25 \\
26 \\
27 \\
28 \\
29 \\
30 \\
31 \\
32 \\
33 \\
34 \\
35 \\
36 \\
37 \\
38 \\
39 \\
40 \\
41 \\
42 \\
43 \\
44 \\
45 \\
46\end{array}$ & $\begin{array}{r}237.0 \\
231.0 \\
220.0 \\
200.4 \\
183.0 \\
223.3 \\
228.0 \\
158.0 \\
131.0 \\
435.0 \\
303.5 \\
184.6 \\
395.5 \\
346.0 \\
207.5 \\
254.5 \\
294.0 \\
233.2 \\
380.0 \\
332.0 \\
333.5 \\
341.5 \\
296.0 \\
281.0 \\
231.1 \\
334.2 \\
286.0 \\
74.5 \\
82.5 \\
74.0 \\
268.0 \\
78.0 \\
92.5 \\
235.0 \\
237 \\
293.5 \\
211.0 \\
294.8\end{array}$ & $\begin{array}{r}50.0 \\
52.2 \\
57.6 \\
46.9 \\
42.6 \\
51.3 \\
54.0 \\
38.7 \\
33.3 \\
104.3 \\
73.6 \\
42.7 \\
91.9 \\
84.0 \\
46.1 \\
69.2 \\
69.8 \\
54.3 \\
71.8 \\
73.0 \\
766 \\
66.4 \\
59.4 \\
50.1 \\
95.2 \\
61.9 \\
16.3 \\
18.4 \\
15.7 \\
60.6 \\
16.0 \\
20.6 \\
54.5 \\
53.9 \\
69.0 \\
47.9 \\
63.0\end{array}$ & $\begin{array}{r}151.0 \\
161.8 \\
150.3 \\
146.0 \\
132.4 \\
162.8 \\
152.2 \\
117.5 \\
96.7 \\
308.3 \\
217.0 \\
139.0 \\
276.5 \\
239.0 \\
135.5 \\
175.8 \\
191.8 \\
160.2 \\
257.0 \\
214.0 \\
205.0 \\
206.3 \\
197.8 \\
174.6 \\
150.2 \\
216.0 \\
182.3 \\
55.5 \\
59.3 \\
551.1 \\
181.0 \\
57.4 \\
66.4 \\
152.2 \\
155.7 \\
192.5 \\
139.5 \\
180.7\end{array}$ & $\begin{array}{l}201.0 \\
214.2 \\
208.9 \\
192.9 \\
175.0 \\
214.1 \\
206.2 \\
156.2 \\
130.0 \\
412.6 \\
290.6 \\
181.7 \\
368.4 \\
323.0 \\
181.6 \\
245.0 \\
261.6 \\
214.5\end{array}$ & $\begin{array}{r}7.07 \\
7.98 \\
8.23 \\
7.13 \\
6.57 \\
8.49 \\
7.85 \\
6.22 \\
5.82 \\
15.45 \\
9.73 \\
7.45 \\
13.51 \\
11.52 \\
7.19 \\
9.11 \\
9.87 \\
8.30 \\
10.70 \\
10.90 \\
9.65 \\
8.93 \\
7.70 \\
11.99 \\
9.40 \\
2.96 \\
3.43 \\
3.15 \\
8.95 \\
3.40 \\
3.41 \\
7.70 \\
7.95 \\
10.30 \\
7.50 \\
9.28\end{array}$ & $\begin{array}{r}6.65 \\
8.00 \\
7.13 \\
8.20 \\
6.40 \\
8.30 \\
7.60 \\
5.94 \\
5.45 \\
14.10 \\
8.80 \\
6.62 \\
12.40 \\
12.30 \\
7.75 \\
8.85 \\
9.75 \\
11.82 \\
10.40 \\
10.55 \\
11.60 \\
11.04 \\
8.90 \\
8.30 \\
11.40 \\
9.72 \\
3.00 \\
3.35 \\
9.13 \\
3.96 \\
7.92 \\
7.92 \\
10.92 \\
7.15 \\
9.24\end{array}$ & $\begin{array}{r}14.60 \\
13.70 \\
14.76 \\
14.03 \\
12.42 \\
\\
20.63 \\
11.93 \\
23.80 \\
12.68 \\
17.74 \\
18.55 \\
15.60 \\
22.0 \\
\\
21.65 \\
19.15 \\
17.30 \\
15.00 \\
17.50 \\
5.12 \\
5.67 \\
55.45 \\
17.70 \\
5.35 \\
5.96 \\
15.85 \\
15.40 \\
20.60 \\
13.80 \\
18.50\end{array}$ \\
\hline \multicolumn{8}{|c|}{ Rats receiving isotonic saline } \\
\hline $\begin{array}{l}1 \\
2 \\
3 \\
4 \\
5 \\
48 \\
49 \\
51 \\
52 \\
53\end{array}$ & $\begin{array}{l}259.0 \\
248.7 \\
267.6 \\
247.5 \\
280.0 \\
260.2 \\
307.0 \\
281.5 \\
261.5 \\
269.0\end{array}$ & $\begin{array}{l}62.9 \\
60.4 \\
66.1 \\
60.3 \\
69.2 \\
60.4 \\
74.6 \\
66.8 \\
59.5 \\
66.8\end{array}$ & $\begin{array}{l}177.7 \\
170.3 \\
182.6 \\
166.6 \\
192.2 \\
170.5 \\
204.5 \\
195.0 \\
166.0 \\
179.5\end{array}$ & $\begin{array}{l}240.6 \\
230.7 \\
248.7 \\
226.9 \\
261.4 \\
230.9 \\
279.1 \\
261.8 \\
225.5 \\
246.3\end{array}$ & $\begin{array}{r}8.81 \\
9.14 \\
9.88 \\
8.54 \\
9.90 \\
9.29 \\
10.97 \\
9.55 \\
9.04 \\
8.95\end{array}$ & $\begin{array}{r}9.84 \\
8.52 \\
9.42 \\
9.00 \\
10.20 \\
9.28 \\
10.65 \\
9.94 \\
9.40 \\
9.15\end{array}$ & \\
\hline
\end{tabular}

* Determined by alkaline ash-microdiffusion method. Corrected for chloride content of serum taken for analysis

were weighed into a platinum crucible and ashed at $550^{\circ} \mathrm{C}$. for 12 hours. The ash was taken up with $1 \mathrm{ml}$. of $1 \mathrm{~N} \mathrm{HCl}$, washed over into a 50-ml. volumetric flask and made up to volume. Aliquots of this solution were used for the flame photometer, for potassium analyses.

\section{RESULTS}

The agreement between replicate determinations (Tables I and II) of carcass chloride by each of the three methods has been assessed by calculation of the standard error of analysis ${ }^{4}$ from the results of

4 The standard error of analysis gives the range within one standard deviation in which the results of analysis will fall about a theoretical parameter expressing the average of an infinite number of similar analyses. The range for the average of duplicate analyses is obtained by dividing the SE. for a single analysis by $\sqrt{2}$; for the average of triplicate analyses, by dividing by $v \overline{3}$, etc. 
TABLE II

Standard error of analysis (SE) for three methods of carcass chloride determination *

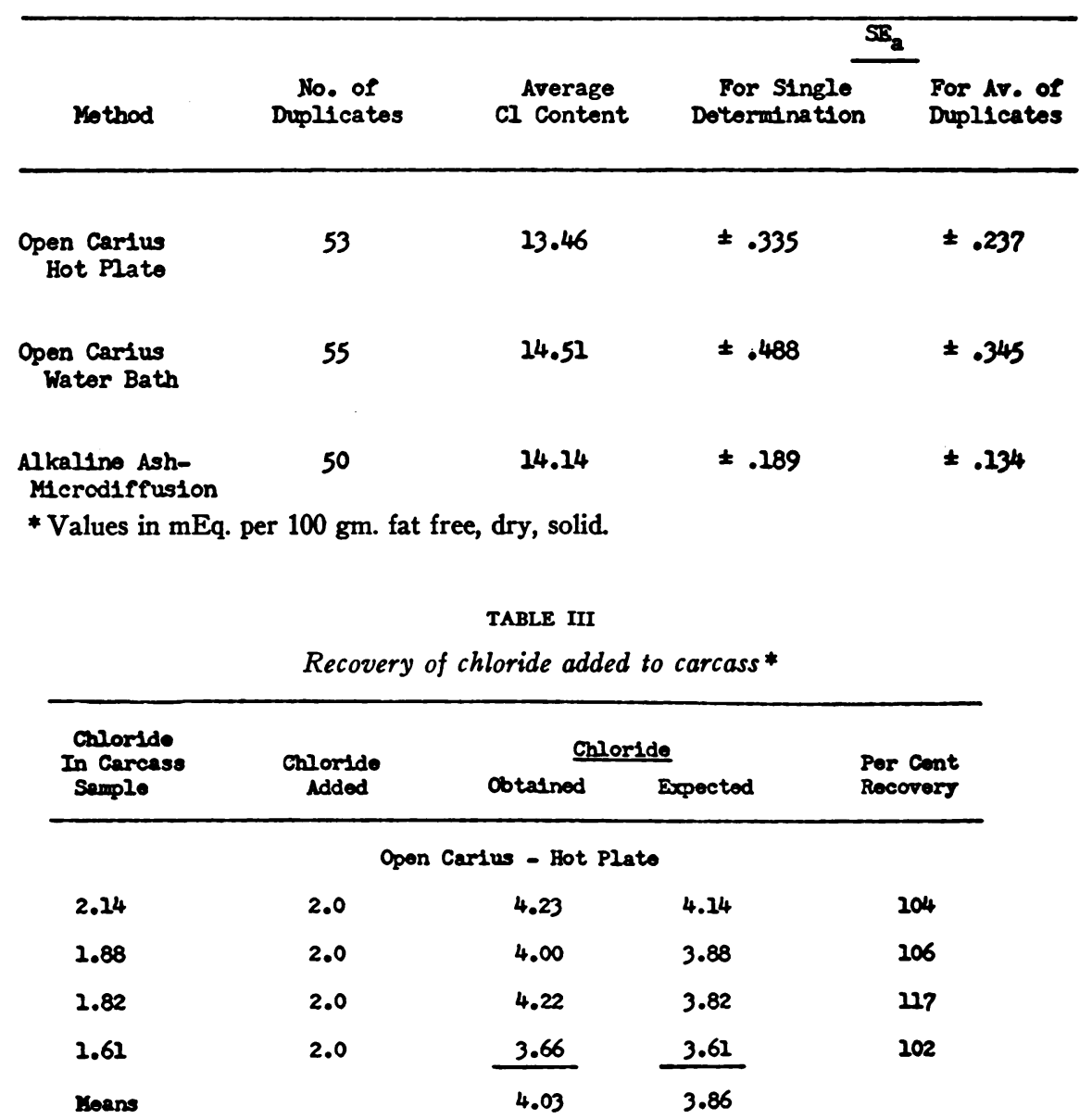

Open Carlus - Wator Bath

$\begin{array}{lllll}2.46 & 2.0 & 4.48 & 4.46 & 101 \\ 1.86 & 2.0 & 3.96 & 3.86 & 105 \\ 2.48 & 2.0 & 4.57 & 4.48 & 104 \\ 2.08 & 2.0 & 4.24 & 4.08 & 108 \\ \text { Hoans } & & 4.31 & \frac{4.22}{}\end{array}$

Alkearine Ash - Merodiffusion

$\begin{array}{rrrrr}2.22 & 1.0 & 3.21 & 3.22 & 99 \\ 2.22 & 1.0 & 3.23 & 3.22 & 101 \\ 2.20 & 1.0 & 3.22 & 3.20 & 102 \\ 2.17 & 1.0 & 3.14 & 3.27 & 97 \\ 2.42 & 1.0 & 3.44 & 3.41 & 103 \\ 2.25 & 1.0 & 3.24 & 3.25 & 99 \\ \text { roans } & & 3.25 & \frac{3.25}{} & \end{array}$

* Values are in $\mu \mathrm{Eq}$. 
TABLE IV

Results of carcass chloride analysis by open Carius and alkaline ash-microdiffusion methods $\dagger$

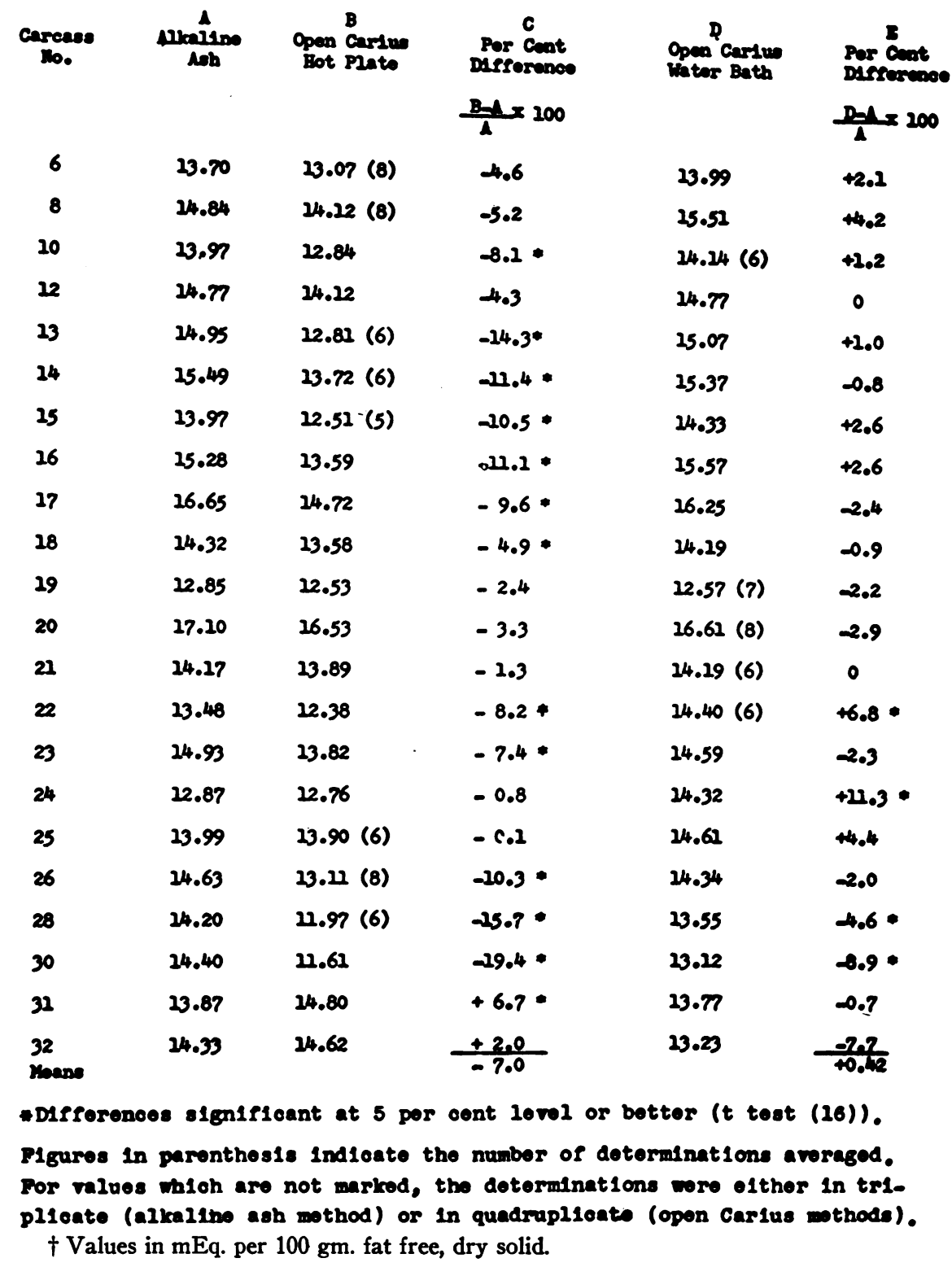

duplicate determinations. The formula used was

$$
\mathrm{SE}_{\mathrm{a}}=\sqrt{\frac{2 \mathrm{~d}^{2}}{2 \mathrm{~N}}}
$$

in which $\mathrm{SE}_{\mathrm{a}}$ is the standard error of analysis, $\mathrm{N}$, the number of paired observations, and d, the difference between the results of duplicate analyses. The standard errors, calculated from approximately 50 duplicate analyses by each of the three methods, are shown in Table II. Reproducibility was best for determinations by the alkaline ashmicrodiffusion method ${ }^{5}$ and poorest with the open Carius method with water bath digestion. The results of recovery experiments with each

5 A single analysis by the alkaline ash-microdiffusion method was taken as the result of a single ashing. Since the chloride content of each ash was determined by quadruplicate analyses by the microdiffusion procedure, the titrimetric error for this method is negligible as compared with the open Carius method in which a single titration determined the result of each analysis. 
TABLE V

Results of muscle chloride analysis by open Carius and alkaline ash-microdiffusion method *

Alkaline

Ash

Open Carius
Hot Plate

Ruman Nuscle (Autopsy)

$\begin{array}{lll}13.44 & - & 12.66 \\ 18.22 & - & 17.94 \\ 9.54 & \ldots & 8.77 \\ 8.78 & \ldots & 6.85 \\ 10.42 & \ldots & 10.12 \\ 9.97 & \ldots & 10.27 \\ 16.36 & -- & 14.88 \\ 22.27 & \ldots & 19.47\end{array}$

Dog Musclo

7.33

7.36

6.70

Rat Musclo

6.15

3.14

5.50

* Values in mEq. per $100 \mathrm{gm}$. fat free, dry solid.

of the three methods are given in Table III. Chloride was added to fat free, dry carcass as potassium chloride. With the open Carius techniques, the amount of chloride recovered tended to be greater than the amount added. Agreement between expected and found was much better with the alkaline ash-microdiffusion method.

Table IV compares the values for carcass chloride as determined by each of the three methods. The values represent the means of triplicate analyses by the alkaline ash-microdiffusion method and of quadruplicate or more analyses by the Carius methods. For the comparison, the values obtained by the alkaline ash method have been used as the standard of reference. With the open Carius procedure and hot plate digestion, the values were usually lower than those obtained with the alkaline ash-microdiffusion method. ${ }^{6}$ The mean

- In reconciling the generally lower values for carcass chloride obtained by the hot plate-open Carius method with the fact that recovery experiments with this method usually yielded too much chloride, it can only be assumed that the original analyses of the specimens to which chloride was added were in error. If these values were too low, and the analyses after chloride addition more nearly correct, the apparent recovery of too great an amount of chloride would result. percentage difference was -7.0 . In over half of the instances, the differences were statistically significant $(\mathrm{p}<.05)$. On the other hand, with digestion on a boiling water bath, the results using the open Carius method were, in the main, comparable to those obtained by the alkaline ash method. In only four of the 22 instances were the Carius values significantly lower $(p<.05)$ than those obtained by the alkaline ash procedure. The average difference amounted to +0.4 per cent.

In Table $\mathrm{V}$ values for muscle analyses for chloride by each of the three methods are compared. The specimens of muscle were obtained from children who had died from various diseases and from a normal dog and rat. In the majority of instances, the results for the Carius method employing a water bath are slightly lower than the values obtained by alkaline ashing.

In Figure 1 the total chloride as determined from the volume of distribution of bromide has been plotted against total chloride determined by carcass analysis by the alkaline ash-microdiffusion technique. The data are for 35 rats receiving tap water (solid circles) and for 10 rats receiving 0.9 per cent $\mathrm{NaCl}$ for drinking (open circles). For both groups the points fall fairly close to the

TOTAL CHLORIDE BY CARCASS ANALYSIS PLOTTED AGAINST EXCHANGEABLE CHLORIDE OBTAINED BY BROMIDE INJECTION

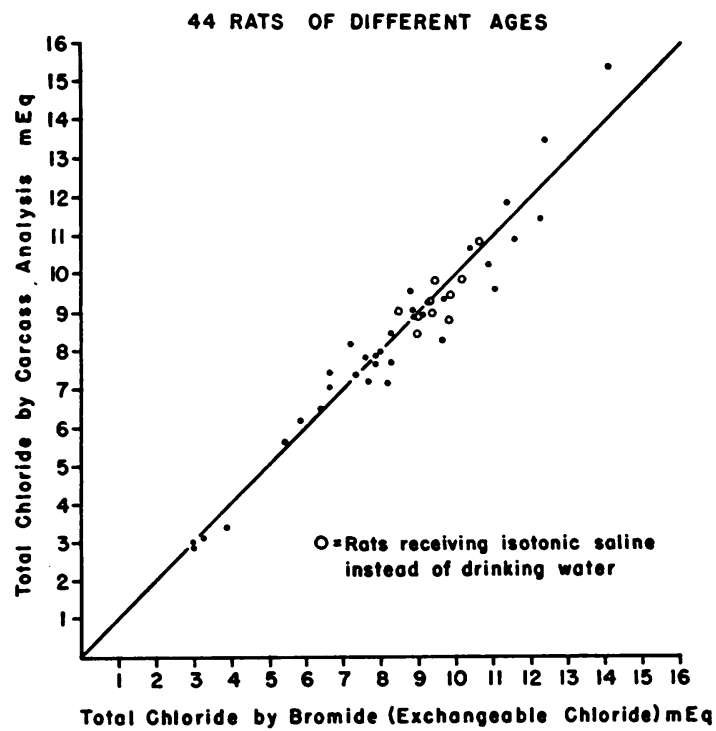

Fig. 1. Total Chlortoe by Carcass Analysis (Alraline Ash-Microdiffusion Method) vs. Bromide Exchangeable Chloride

The line denotes equality of the two measurements. 


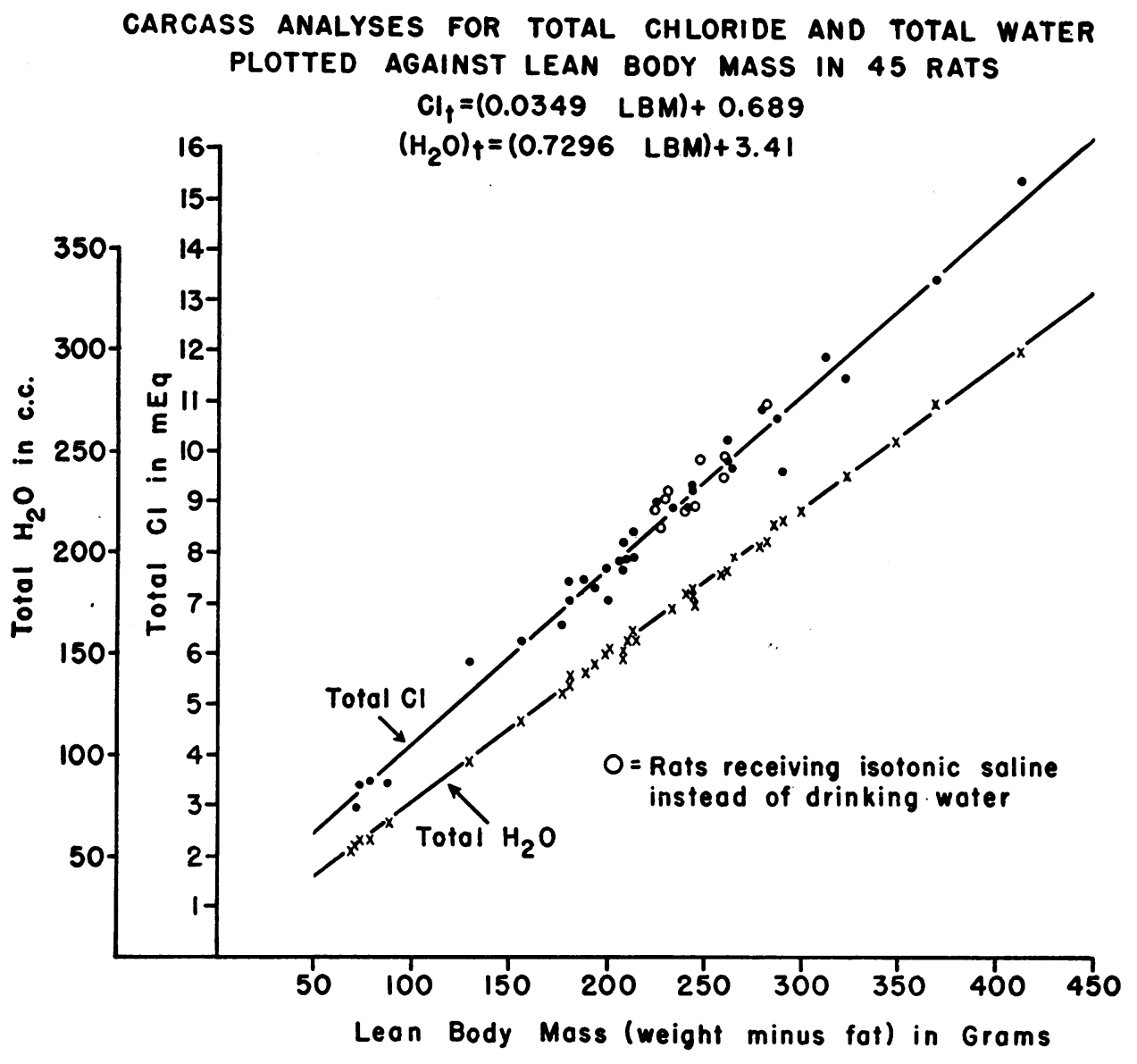

Figure 2

line denoting equality of the two measurements. The greatest deviations from equality were found in four animals in which total chloride measured by bromide differed by 10 to 15 per cent from the values obtained by carcass analysis. Statistical analysis of the data for all animals gave a mean value of $8.45 \mathrm{mEq}$. for total chloride measured by bromide and $8.48 \mathrm{mEq}$. for total chloride measured by carcass analysis. The coefficient of variation between the two methods was 5.04 per cent. ${ }^{7}$ Mean values for carcass chloride determined by the open Carius method with water bath digestion also agreed well with total chloride measured by bromide; with hot plate digestion however, carcass chloride values were lower. In 21 rats, chlo-

7 The coefficient of variation was determined by the expression, $\mathrm{SE}_{a} / \mathrm{Mean} \times 100$, in which $\mathrm{SE}_{2}$ is the standard error of analysis calculated as described in the text from the results of the alkaline ash and exchangeable chloride estimations for each rat. ride measured by bromide distribution averaged $8.87 \mathrm{mEq}$. as compared with $8.91 \mathrm{mEq}$. by carcass analysis by the open Carius-water bath digestion method, and $8.36 \mathrm{mEq}$. by the open Carius method with hot plate digestion. Judging from the results of the alkaline ash and open Carius-water bath digestion methods, the exchangeable chloride as measured by bromide would seem to be very close to true total body chloride. Failure of agreement between exchangeable chloride and carcass chloride as seen in certain animals may be attributable to the summation of technical errors, particularly in the exchangeable chloride method. It should be recalled that the determination of total chloride indirectly by bromide distribution depends on accurate measurements of the amount of bromide injected, of the serum bromide and chloride levels, and assumes the blank value for serum bromide to be the same in all rats. The carcass analysis, on the other hand, 
depends only on accuracy in the measurement of the weight of fat free, dry solid and tissue chloride.

In Figure 2, carcass chloride, determined by the alkaline ash-microdiffusion method, and total body water, obtained by desiccation, have been plotted against lean body mass (weight minus etherextractable fat). Over the range investigated, both total water and total chloride are linearly related to lean body mass, not only in the rats maintained on tap water but also in those given 0.9 per cent $\mathrm{NaCl}$ for drinking. The regression equations expressing the relations between these variables, calculated by the method of least squares, were

$$
\mathrm{Cl}_{\mathrm{t}}=0.0349 \mathrm{LBM}+0.689
$$

and

$$
\left(\mathrm{H}_{2} \mathrm{O}\right)_{\mathrm{t}}=0.730 \mathrm{LBM}+3.41
$$

in which $\mathrm{Cl}_{\mathbf{t}}$ is the total chloride in $\mathrm{mEq}$., $\left(\mathrm{H}_{2} \mathrm{O}\right)_{t}$, total water in ml. and LBM, the lean body mass in grams. The standard error of the estimate for the regression of total chloride vs. LBM was $\pm 0.38 \mathrm{mEq}$. and for that of total water vs. LBM, $\pm 2.1 \mathrm{ml}$.

Since LBM is, by definition, the sum of the fat free, dry solids and total water (FFDS + $\left.\left(\mathrm{H}_{2} \mathrm{O}\right)_{t}\right)$, the expression LBM - FFDS may be substituted for $\left(\mathrm{H}_{2} \mathrm{O}\right)_{t}$ in equation (2) and LBM expressed in terms of fat free, dry solid as

$$
\mathrm{LBM}=3.69 \text { FFDS }+12.61
$$

When carcass chloride determined by the open Carius method with water bath digestion was plotted $v s$. lean body mass, the configuration was almost identical to that shown in Figure 2 for the alkaline ash method. The regression, calculated for 22 rats, was also similar to equation (1);

$$
\mathrm{Cl}_{\mathrm{t}}=0.0338 \mathrm{LBM}+0.910
$$

The standard error of the estimate was somewhat greater, amounting to $\pm 0.44 \mathrm{mEq}$.

The relation between total body potassium $\left(\mathrm{K}_{\mathrm{t}}\right)$, as obtained by carcass analysis, and lean body mass is shown in Figure 3. Again, a linear relation pertains. The calculated regression was

$$
\mathrm{K}_{\mathrm{t}}=0.0747 \mathrm{LBM}-0.330
$$

The standard error of the estimate was \pm 0.70 $\mathrm{mEq}$.

The equation for total water $v s$. lean body mass (equation 2) is similar to that calculated by Pace and Rathbun (17) from the data of Ashworth and Cowgill (18). The slope in their equation, 0.721,

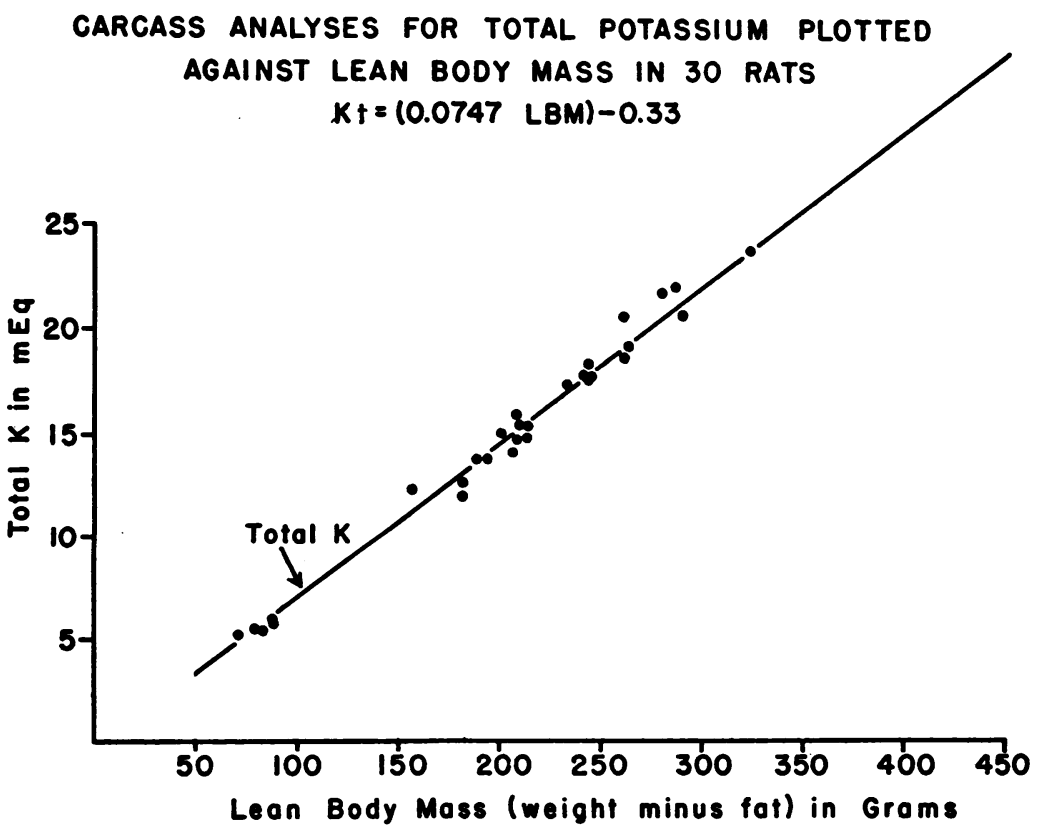

Figure 3 
is almost identical, while the intercept, 1.76 is lower, probably because smaller rats were used. For the adult rats in the present series, the body water expressed as percentage of lean body mass is 73.8, a value in good agreement with the average value of 73.2 derived by Pace and Rathbun (17) from their own work and that of others on a number of species.

It should be noted that the intercepts in the equations given above indicate that the young rat will have a greater chloride and water content and a somewhat lower potassium content per unit of lean body mass than the adult. Data by Iob and Swanson (19) indicate that in the newborn rat, the relationships between electrolyte content and weight may be curvilinear. For rats two to three weeks of age, their data agree well with those of the present study.

\section{DISCUSSION}

The open Carius method for the determination of chloride in biological fluids was originally introduced by Van Slyke in 1923 (13). In 1928, Wilson and Ball (14) proposed that the method be modified by adding silver nitrate and nitric acid separately, rather than combined in a single reagent as originally described. By adding the silver nitrate first, higher values were obtained. It was suggested by the authors that in the original procedure, chloride was lost as volatile $\mathrm{HCl}$. In 1933, Sunderman and Williams (20) found that the open Carius method with the Wilson and Ball modification gave results that were too low and obtained a 10 to 20 per cent increase in yield if tissues were previously digested with $\mathrm{KOH}$. However, Hastings and Eichelberger (15) stated that if fat free tissues were allowed to stand overnight with silver nitrate prior to the addition of nitric acid, results agreeing with the Sunderman and Williams' method could be obtained. The results of the present study, employing essentially the method of Hastings and Eichelberger, suggest that the temperature of digestion is a critical factor in the accuracy of the open Carius procedure. While most laboratories seem to employ a water bath for tissue chloride digestion, the importance of controlling heat at or below $100^{\circ} \mathrm{C}$. has not been emphasized previously.

In our hands, the alkaline ash-microdiffusion method was superior to the open Carius procedure. Not only were replicate determinations in better agreement and recovery of added chloride more satisfactory, but also the values agreed well with the indirect determination of chloride by bromide distribution. Furthermore, carcass chloride, determined by this procedure, showed little scatter when plotted against lean body mass. It should be noted that with the alkaline ash method, titrimetric error can be reduced to a minimum since multiple titrations can be done on a single ashing. Because the ash of replicate specimens agreed well in chloride content, a single ashing may be done with little sacrifice of accuracy and considerable economy of tissue.

The source of error with the open Carius method is somewhat obscure. The lower values generally obtained when the hot plate was used suggest that chloride may be lost during digestion at high temperatures. Supporting this assumption is the fact that digestion on a boiling water bath usually gave higher values which were in agreement with the alkaline ash procedure. On the other hand, there were indications that other factors may be operative. It was frequently noted that whereas multiple analyses run concurrently often showed good agreement, another series of analyses on the same specimen at a later time gave values differing significantly. The factor responsible for these discrepancies was not determined with certainty. They may have been the result of small differences in the temperature of digestion. Towards the end of the study, it was found that the temperature of the digestion mixtures varied, depending upon the adequacy of covering the tubes. With the tubes in the water bath, uncovered, the temperature of the digestion mixture was $93^{\circ} \mathrm{C}$., and with the tubes covered with inverted glass thimbles, $97^{\circ} \mathrm{C}$. On the hot plate, the temperature was as high as $105^{\circ} \mathrm{C}$. with funnels in the tubes, and, without the funnels, $102^{\circ}$ to $103^{\circ} \mathrm{C}$. It would appear that the poor reproducibility observed with the open Carius procedure may be related to factors concerned with the transfers of heat and to variations in the temperature of digestion.

The evidence for believing that the volume of distribution of bromide follows closely the volume of distribution of chloride is substantial (21-26). 
TABLE VI

\begin{tabular}{|c|c|c|c|c|}
\hline Investigators & Method & $\begin{array}{l}\text { Number } \\
\text { of dogs }\end{array}$ & mEq. $\mathrm{Cl} / \mathbf{K g}$. & Remarks \\
\hline $\begin{array}{l}\text { Harrison, Darrow, and } \\
\text { Yannet (5) }\end{array}$ & $\begin{array}{c}\text { Carcass } \\
\text { analysis }\end{array}$ & 2 & 33.3 & $\begin{array}{l}\text { Gastrointestinal juices washed } \\
\text { out and discarded }\end{array}$ \\
\hline $\begin{array}{l}\text { Winkler, Elkinton, and } \\
\text { Eisenman (28) }\end{array}$ & $\mathrm{Cl}^{28}$ & 3 & 32.2 & Six-hour space \\
\hline Cheek and West (29) & Stable Br & 13 & 32.5 & Three-hour space \\
\hline $\begin{array}{l}\text { Gamble, Robertson, } \\
\text { Hannigan, Foster, } \\
\text { and Farr (24) }\end{array}$ & $\begin{array}{l}\mathrm{Br}^{82} \\
\mathrm{Cl}^{36} \\
\mathrm{Br}^{82} \\
\mathrm{Cl}^{36}\end{array}$ & $\begin{array}{l}4 \\
4 \\
4 \\
4\end{array}$ & $\begin{array}{l}32.5 \\
30.6 \\
35.2 \\
32.5\end{array}$ & $\begin{array}{l}\text { Three-hour space } \\
\text { Three-hour space } \\
\text { 24-hour space } \\
\text { 24-hour space }\end{array}$ \\
\hline $\begin{array}{l}\text { Burch, Threefoot, } \\
\text { and Ray (30) }\end{array}$ & $\mathrm{Cl}^{36}$ & 5 & 42.5 & $\begin{array}{l}\text { Measured over period of days; } \\
\text { losses in feces and urine esti- } \\
\text { mated; young dogs used }\end{array}$ \\
\hline $\begin{array}{l}\text { Swan, Madisso, and } \\
\text { Pitts (9) }\end{array}$ & $\mathrm{Cl}^{36}$ & 5 & 35.4 & $\begin{array}{l}\text { Lean dogs used } \\
\text { Six-hour space }\end{array}$ \\
\hline Weir (26) & Stable Br & 5 & 35.5 & $\begin{array}{l}\text { 24-hour space } \\
\mathrm{Cl}=39.5 \mathrm{mEq} \text {./kilo of lean } \\
\text { weight }\end{array}$ \\
\hline
\end{tabular}

The volumes of distribution of $\mathrm{Cl}^{36}, \mathrm{Cl}^{38}$ and $\mathrm{Br}^{82}$ agree closely when determined simultaneously in man (24) or dog (25). The present finding that the mean values for exchangeable chloride approximate closely the carcass chloride under normal conditions, and conditions of salt loading, lends further credence to the above supposition. The data would indicate that in the rat, as noted by others in the dog (27) and human $(10,24)$, a three-hour period for equilibration of bromide seems to be sufficient for penetration of the chloride space.

Fat is a variable quantity in the body and it is not possible to compare accurately data obtained from one animal with those from another unless the results are expressed in terms of lean body mass or fat free, dry solid. In Table VI the results of chloride analyses of the whole carcass of two dogs by Harrison, Darrow, and Yannet (5) may be compared with the data for dogs obtained by isotopes of $\mathrm{Cl}$ or by bromide distribution. It can be seen that these data even when uncorrected for fat, compare favorably. It should be noted in passing that the results of Burch, Threefoot, and Ray (30) were derived from the investigation of young dogs and their data are at variance with those of other investigators.

Many workers in presenting data on total body electrolyte have followed the principles established by Needham (31) and have plotted total electrolyte on a double logarithmic grid using body weight as a standard of reference $(11,19,32,33)$. Such plots are of value in that they emphasize the exponential nature of growth. It has been shown that from early life to maturity, chemical growth with respect to chloride and sodium can be expressed by a simple exponential function $(11,32)$. When data for total electrolyte (34) are plotted against body weight on an arithmetic grid, considerable scatter is evident whereas in double logarithmic plots the scatter is not conspicuous. It would appear that a large part of such scatter is the result of the variable contribution of body fat to body weight. The present study demonstrates that for chloride and potassium in the rat, a close correlation exists between the body content of these electrolytes and lean body mass.

\section{SUMMARY}

Three methods of tissue chloride analysis have been compared : 1) The open Carius method with digestion of the tissue by boiling on a hot plate; 2) the open Carius method with digestion in a boiling water bath; and 3) an alkaline ash procedure with determination of chloride by the microdiffusion technique of Conway. Of the three methods, the alkaline ash-microdiffusion method gave better agreement with respect to 
repeated analyses. When chloride was added to fat free, dry carcass, the microdiffusion method demonstrated a more satisfactory recovery. Although the values obtained by the open Carius method with boiling water bath digestion were less reproducible than with the alkaline ash method, the averages of replicate determinations by the two methods were in good agreement. On the other hand, the employment of a hot plate for digestion during the Carius procedure frequently gave values that were significantly low. The heat at which digestion is carried out appears to be an important factor in the accuracy of the open Carius procedure.

The exchangeable chloride has been measured in 45 rats by determination of the volume of distribution of bromide. The same rats were then sacrificed and reduced to a fat-free, dry, fine, homogeneous powder suitable for chloride analysis. It was found that total carcass chloride in rats closely approximates exchangeable chloride. The substitution of isotonic saline for drinking water did not alter exchangeable chloride or carcass chloride to any appreciable extent.

The agreement obtained for total rat chloride by the use of bromide and by two methods of carcass analysis supports the contention that all the chloride in the rat has been accurately accounted for.

It has been found that total body chloride, water and potassium exhibit a simple linear relationship to lean body mass. Such relationships should facilitate the investigation of abnormal states of electrolyte balance.

\section{REFERENCES}

1. Nichols, G., Jr., Nichols, N., Weil, W. B., and Wallace, W. M., The direct measurement of the extracellular phase of tissues. J. Clin. Invest., 1953, 32, 1299.

2. Cotlove, E., Mechanism and extent of distribution of inulin and sucrose in chloride space of tissues. Am. J. Physiol., 1954, 176, 396.

3. Manery, J. F., and Hastings, A. B., The distribution of electrolytes in mammalian tissues. J. Biol. Chem., 1939, 127, 657.

4. Gersh, I., Distribution of chloride in the gastric mucous membrane of the dog. Proc. Soc. Exper. Biol. \& Med., 1938, 38, 70.

5. Harrison, H. E., Darrow, D. C., and Yannet, H., The total electrolyte content of animals and its probable relation to the distribution of body water. J. Biol. Chem., 1936, 113, 515.

6. Gardner, L. I., Talbot, N. B., Cook, C. D., Berman, H., and Uribe, R. C., The effect of potassium deficiency on carbohydrate metabolism. J. Lab. \& Clin. Med., 1950, 35, 592.

7. Harrison, H. E., and Darrow, D. C., The distribution of body water and electrolytes in adrenal insufficiency. J. Clin. Invest., 1938, 17, 77.

8. Heilbrunn, L. V., and Hamilton, P. G., The presence of chloride in muscle fibers. Physiol. Zoöl., 1942, 15, 363.

9. Swan, R. C., Madisso, H., and Pitts, R. F., Measurement of extracellular fluid volume in nephrectomized dogs. J. Clin. Invest., 1954, 33, 1447.

10. Cheek, D. B., Estimation of the bromide space with a modification of Conway's method. J. Appl. Physiol., 1953, 5, 639.

11. Cheek, D. B., Observations on total body chloride in children. Pediatrics, 1954, 14, 5.

12. Conway, E. J., Microdiffusion Analysis and Volumetric Error. 3rd ed. rev., London, C. Lockwood, 1950, Chaps. 23 and 24.

13. Van Slyke, D. D., The determination of chlorides in blood and tissues. J. Biol. Chem., 1923, 58, 523.

14. Wilson, D. W., and Ball, E. G., A study of the estimation of chloride in blood and serum. J. Biol. Chem., 1928, 79, 221.

15. Hastings, A. B., and Eichelberger, L., The exchange of salt and water between muscle and blood; I. The effect of an increase in total body water produced by the intravenous injection of isotonic salt solutions. J. Biol. Chem., 1937, 717, 73.

16. Fisher, R. A., Statistical Methods for Research Workers. 5th ed., Edinburgh, Oliver and Boyd, 1934.

17. Pace, N., and Rathbun, E. N., Studies on body composition; III. The body water and chemically combined nitrogen content in relation to fat content. J. Biol. Chem., 1945, 158, 685 .

18. Ashworth, U. S., and Cowgill, G. R., Body composition as a factor governing the basal heat production and the endogenous nitrogen excretion. J. Nutrition, 1938, 15, 73.

19. Iob, V., and Swanson, W. W., Mineral growth. Growth, 1938, 2, 253.

20. Sunderman, F. W., and Williams, P., The analysis of chloride in tissues. J. Biol. Chem., 1933, 102, 279.

21. Wallace, G. B., and Brodie, B. B., The distribution of iodide, thiocyanate, bromide and chloride in the central nervous system and spinal fluid. $J$. Pharmacol. \& Exper. Therap., 1939, 65, 220.

22. Wallace, G. B., and Brodie, B. B., The distribution of administered bromide in comparison with chloride and its relation to body fluids. J. Pharmacol. \& Exper. Therap., 1939, 65, 214.

23. Weir, E. G., and Hastings, A. B., The distribution of bromide and chloride in tissues and body fluids. J. Biol. Chem., 1939, 129, 547.

24. Gamble, J. L., Jr., Robertson, J. S., Hannigan, C. A., Foster, C. G., and Farr, L. E., Chloride, bromide, 
sodium, and sucrose spaces in man. J. Clin. Invest., 1953, 32, 483.

25. Gamble, J. L., Jr., and Robertson, J. S., Volume of distribution of radioactive chloride in dogs; comparisons with sodium, bromide and inulin spaces. Am. J. Physiol., 1952, 171, 659.

26. Weir, E. G., Further observations on total chloride content; the relationship between body fat and body chloride. Am. J. Physiol., 1940, 130, 608.

27. Brodie, B. B., Brand, E., and Leshin, S., The use of bromide as a measure of extracellular fluid. $J$. Biol. Chem., 1939, 130, 555.

28. Winkler, A. W., Elkinton, J. R., and Eisenman, A. J., Comparison of sulfocyanate with radioactive chloride and sodium in the measurement of extracellular fluid. Am. J. Physiol., 1943, 139, 239.

29. Cheek, D. B., and West, C. D., Unpublished data.
30. Burch, G. E., Threefoot, S. A., and Ray, C. T., Rates of turnover and biologic decay of chloride and chloride space in the dog determined with the long-life isotope, $\mathrm{Cl}^{\star}$. J. Lab. \& Clin. Med., 1950, $35,331$.

31. Needham, J., Chemical heterogony and the groundplan of animal growth. Biol. Revs., 1934, 9, 79.

32. Forbes, G. B., and Perley, A., Estimation of total body sodium by isotopic dilutions. II. Studies on infants and children: An example of a constant differential growth ratio. J. Clin. Invest., 1951, $30,566$.

33. Forbes, G. B., Chemical growth in infancy and childhood. J. Pediat., 1952, 41, 202.

34. Forbes, G. B., and Perley, A., Estimation of total body sodium by isotopic dilution. I. Studies on young adults. J. Clin. Invest., 1951, 30, 558. 